\title{
Recognition of Devoiced Vowels Using Optical Microphone Made of Multipled POF-Type Moisture Sensors
}

\author{
Masayuki Morisawa Member (University of Yamanashi) \\ Yoichi Natori Non-member (University of Yamanashi) \\ Tomohito Taki Non-member (University of Yamanashi) \\ Shinzo Muto Non-member (University of Yamanashi)
}

Keywords: Plastic Optical Fiber (POF), swelling polymer, optical fiber moisture sensor, devoiced breath, vowel recognition, DP matching

Conversation is the most practical and common form of communication. However, people with a verbal handicap feel a difficulty in producing words due to variations in vocal chords. This research has led to the development of a new devoiced microphone system based on differences between the moisture patterns for each devoiced breath, using a plastic optical fiber (POF) moisture sensor.

Figure 1 shows the sensor head structure of the POF-type moisture sensor with fast response. In this head, a moisturesensitive polymer with a slightly larger refractive index than that of a fiber core, which causes swelling by attachment of water molecules, was coated on the fiber core with a diameter of $0.5 \mathrm{~mm}$. So,in a dry state, this sensor head is a leaky type.

In the experiment, five sensor heads were used and were set in front of the mouth. When these sensors are exposed to humid atmosphere produced by devoiced breath, the refractive index in the cladding layer begins to decrease by swelling and then the POF sensor heads change to a guided type. This means that the output light intensities from each sensor head change.

Based on the above operation principle, we fabricated measurement system for the recognition of devoiced vowels as shown in Fig. 2. From the output light intensity changes of the five sensor heads, characteristic response patterns for the vowels in Japanese $(\mathrm{a}, \mathrm{i}, \mathrm{u}, \mathrm{e}, \mathrm{o})$ were obtained. Then, we used the dynamic programming matching (DP-matching) method to obtain the voice discernment from the experimental response patterns. The values of 120 dimension vectors, which were obtained from the output signal of five POF sensor heads for 4.8 seconds sampled by 0.2 seconds, were used as the input patterns for the DP matching. As reference patterns, two or more patterns for one vowel are necessary, because output signals from the five POF sensors are different according to the direction of the mouth or strength of the breath. So, in order to obtain the most suitable reference patterns, we used the Iso-data algorithm combined with the DP matching from 300 training input patterns. The result

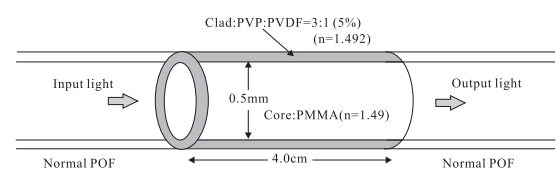

Fig. 1. Structure of POF-type moisture sensor

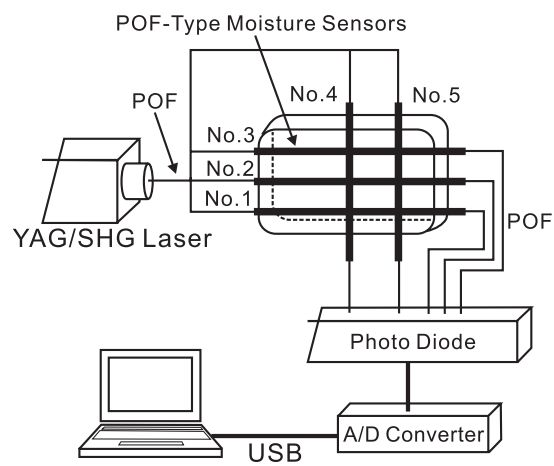

Fig. 2. Measurement system of moisture pattern in devoiced vowel breath.

Table 1. Result of vowel recognition for five devoiced breaths.

\begin{tabular}{l|l|l|l|l|l|l}
\hline & Distinction rate & {$[\mathrm{a}]$} & {$[\mathrm{i}]$} & {$[\mathrm{u}]$} & {$[\mathrm{e}]$} & {$[\mathrm{o}]$} \\
\hline Subject 1 & $95.8 \%$ & $87.0 \%$ & $97.0 \%$ & $100 \%$ & $98.9 \%$ & $97.9 \%$ \\
Subject 2 & $93.6 \%$ & $100 \%$ & $99.3 \%$ & $86.9 \%$ & $91.3 \%$ & $93.2 \%$ \\
Subject 3 & $94.6 \%$ & $87.1 \%$ & $88.5 \%$ & $100 \%$ & $98.9 \%$ & $97.9 \%$ \\
Subject 4 & $97.0 \%$ & $88.1 \%$ & $98.7 \%$ & $100 \%$ & $98.7 \%$ & $98.9 \%$ \\
Subject 5 & $97.4 \%$ & $88.7 \%$ & $100 \%$ & $99.2 \%$ & $100 \%$ & $95.0 \%$ \\
\hline
\end{tabular}

is shown in Table 1. From Table 1, a distinction rate of over $93 \%$ was obtained for five Japanese devoiced vowels. Therefore, using this system and a voice synthesizer, development of a new microphone for people with a functional disorder in the vocal chords seems to be possible. At present, trials to distinguish of devoiced consonants is underway in our laboratory. 


\title{
マルチPOF 水分センサによる光マイクロホン構成と 無声母音識別
}

\author{
正 員 森澤 正之* 非会員 名取 洋一* \\ 非会員 瀧 智仁* 非会員 武藤 真三*
}

\author{
Recognition of Devoiced Vowels Using Optical Microphone Made of Multipled \\ POF-Type Moisture Sensors \\ Masayuki Morisawa*, Member, Yoichi Natori*, Non-member, Tomohito Taki*, Non-member, \\ Shinzo Muto*, Non-member
}

\begin{abstract}
A novel optical fiber microphone system for recognizing devoiced vowels has been studied. This system consists of the optical detection of moisture pattern formed by devoiced breath and its recognization process using a modified DP-matching. To detect moisture pattern of devoiced vowels, five plastic optical fiber moisture sensors with fast response were developed and used. Using this system, high discernment rate over $93 \%$ was obtained for the devoiced vowels. This system will be used for verbally handicapped people to create sounds with a small effort in the near future.
\end{abstract}

キーワード : プラスチック光ファイバ, 膨潤性ポリマ, 光ファイバ水分センサ, 無声音呼気, 母音認識, DP マッチング

Keywords: Plastic Optical Fiber (POF), swelling polymer, optical fiber moisture sensor, devoiced breath, vowel recognition, DP matching

\section{1. まえがき}

音声による会話は，人間の最も一般的なコミュニケーショ ン手段である。しかし，先天的あるいは後天的な障害や事 故などで，その会話を行うことが困難な音声言語障害者や 聴覚障害者が多数存在する。厚生労働省の平成 13 年 6 月 における調査では, 前者は 30.5 万人, 後者は 3.4 万人であ る。音声による会話が困難な人達の主なコミュニケーショ ン手段は，筆談，読話，そして手話である。しかし，これら の方法はかなりの訓練が必要であったり手間がかかったり するため，より簡便なコミュニケーション手段の開発が必 要とされている。そこで本研究では,「会話」に近いコミュ ニケーション手段として，口の形を変えて呼気を出すとき の口付近の水分変化に着目した方法, すなわち, 無声音呼 気中の水分分布の光学的検出による無声母音認識法を提案 する。

一般に，母音の種類によって口の形状は異なり，それに 伴う呼気の空間分布には違いが見られる。この呼気の分布 の差異から無声音の判別を行うことができれば，会話に似

\footnotetext{
*山梨大学

₹ 400-8511 山梨県甲府市武田 4-3-11

University of Yamanashi

4-3-11 Takeda, Kofu, Yamanashi 400-8511
}

たコミュニケーション手段が確立できると考えられる。呼 気の違いを検出する簡便な方法の一つは, 呼気に伴う口周 りの湿度・水分変化を測定することである。しかし，そのた めには応答速度が極めて速く, かつ, 空間的水分分布（以 後, 単に水分分布と略す) も測定可能なセンサヘッドを必要 とする。筆者らはこれまでプラスチックファイバ (Plastic Optical Fiber:POF) を用いた POF 水分センサなどの開 発 (1) (3) を行ってきた。POF は電磁ノイズの影響を受け ない, 安価で軽量, 柔軟性に富む, 大口径のため接続が容 易, 安全性が高いなどの特徴を有しているため, 鼻口近く の水分分布測定のためのセンサとしては最も有望と考えら れる ${ }^{(4)}$ 。加えて, 本 POF 水分センサは従来の水分センサ と比べると速い応答特性を有する。そこで本研究では, こ の $\mathrm{POF}$ 水分センサを複数個用いることによって得られる 水分分布パターンから, 無声音母音の認識を行うことを試 みた。このシステムで得られるデータは, センサの個数分 の次元を持つ時系列データのみのため, 顔の動画像による 音声判別や筋電位による音声認識 (5) (6) よりも容易に処理 が行えると考えられる。ここでは, その基礎的研究として 単音無声音母音の判別を考え, その処理方法としてはDP マッチング法を用いて検討を行った。 


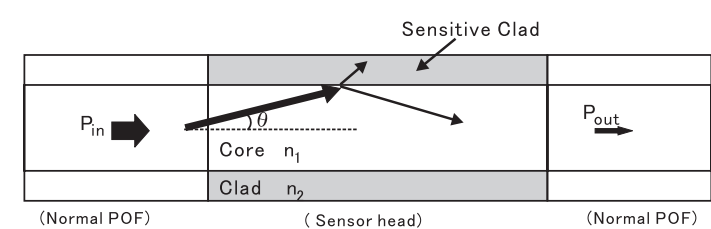

(a) In the dry state: Leaky structure

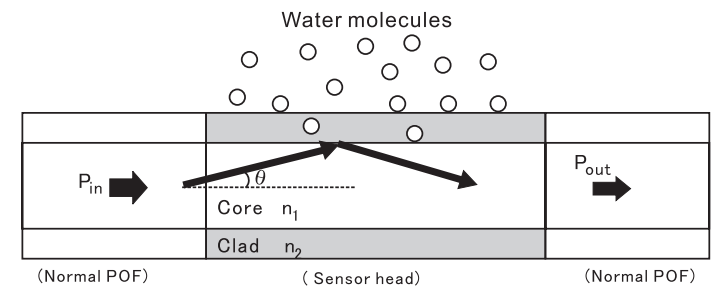

(b) In the humid air: Guided structure

Fig. 1. Operation principle of POF-Type moisture sensor based on structure change in sensor head from leaky-type to guided-one.

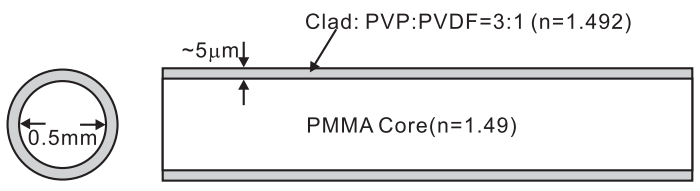

Fig. 2. Sensor head structure of POF-type moisture sensor.

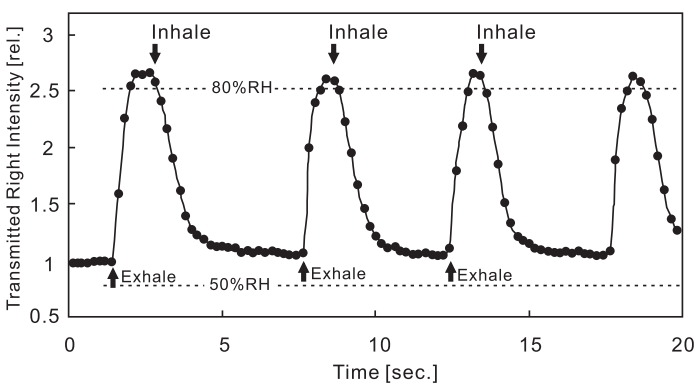

Fig. 3. Observed response of POF-type moisture sensor to normal breath.

\section{2. 高速応答 $\mathrm{POF}$ 水分センサの作製}

数あるポリマの中には，検知対象となる物質に対して選 択的に膨潤性を示し，その屈折率を減少させるものが存在 する。便宜上，検知対象物質がないときのその屈折率を初 期屈折率と呼ぶことにする。そのようなポリマをセンシン グクラッド層（初期屈折率 $n_{2}$ ）として, 屈折率 $n_{1}$ のコア 上にコーティングした POF 型センサヘッドを構成する。こ のとき，初期屈折率 $n_{2}$ を $n_{1}$ より僅かに大きく設定してお くと，センサヘッド部はリーキーPOF 構造となるので透 過光強度は小さいが，検知対象物質（ここでは水分）があ るとセンシングクラッド層は膨潤による屈折率低下を生じ て $n_{2}<n_{1}$ の通常の POF 構造（導波構造）に変化するす るため, 透過光強度は急激に増加することになる。このと き，クラッドとコアの初期屈折率差 $\Delta n=n_{2}-n_{1}>0$ が 小さいほどリーキー構造から導波構造への変換が容易とな
り，センサ感度とともに応答速度も向上する(1)。それらの 様子を幾何光学的モデルで示したのが Fig.1である。

上述の動作機構に基づいたPOF センサとして，これまで ヒドロキシエチルセルロース (HEC) をセンシングクラッ ド層に用いた POF 湿度センサ ${ }^{(2)}$ を開発してきたが，秒 単位で変化する呼気中水分のセンシングには応答が更に速 いPOF 水分センサが必要となる。そのため, 幾つかのポ リマ材料を検討した結果，水分に対する膨潤がより速いポ リビニルピロリドン $\left(\mathrm{PVP}\right.$ と略す； $\left.n_{\mathrm{D}}=1.513\right)$ をセン シングクラッド層に用いた POF 水分センサヘッドを製作 した。Fig.2 にその構造を示す。ポリメチルメタクリル酸 (PMMA と略す； $\left.n_{\mathrm{D}}=1.49\right)$ をコアとする市販 POF（コ ア径 $0.5 \mathrm{~mm}^{\phi}$ ) のクラッド層を 1,4 ジオキサンで除去し, 替 わりのセンシングクラッド層として, PVP と屈折率調整用 ポリ弗化ビニリデン $\left(\mathrm{PVDF}\right.$ と略す; $\left.n_{\mathrm{D}}=1.42\right)$ の混合ポ リマを混合比 3:1 でジメチルスルホキシド溶媒に溶かした ものをディップコーティング法を用いて厚さ 1 数 $\mu \mathrm{m}$ で 塗布した。このとき, PVP と PVDF の混合比を 3:1 とす るとクラッドーコア間初期屈折率差を $\Delta n=0.002$ と十分小 さくすることができ，かつ，PVDF の疎水性によって水分 子の脱着も速くなるため, センサの立上り拈よび立下り応 答を短くすることが期待できる。

製作したPOF 水分センサを用いて測定した呼吸に伴う 鼻口付近の水分変化のモニ夕例を Fig. 3 に示す。同図より 本 POF 水分センサの応答速度は，息を吐き湿度が上昇す るときには約 0.8 秒，息を吸い元に戻るには約 1.7 秒であ る。これより, 呼気に追従できる速い応答を示しているこ とが確認できる。言い換えれば，このセンサはそのまま呼 吸状態センシング用としても利用可能と言える。(7)

\section{POF 水分センサによる無声音母音の特徵抽出}

新たに開発した $\mathrm{POF}$ 水分センサを用いて構成した光ファ イバ無声音マイクロホンとその測定系を Fig.4, Fig.5 に示 す。無声音マイクロホン本体は Fig.4に示すようなマスク型 のケースに $1.5 \mathrm{~cm}$ 間隔で横 3 本, 縦 2 本の $\mathrm{POF}$ 水分セン サを配置したもので，被験者はこれを鼻を支えとして装着す る。測定系は Fig. 5 に示すように光源，導光用 POF，受光 素子㧍よび信号処理系からなる比較的シンプルな構成となっ ている。光源には波長 $532 \mathrm{~nm}$ の YAG/SHG レーザを用い た。レーザからの光は 5 つに分岐されて，それぞれ導光用 POF を通してNo.1 から No.5 までの 5 本のセンサヘッド へと送られる。各 POF 水分センサヘッドからの出力光は 5 本の出力側導光用 $\mathrm{POF}$ を通して受光素子であるフォトダイ オード $(\mathrm{PD})$ へそれぞれ伝送され, その光強度は電圧へと 変換される。その信号は A/D コンバータ (KEYENCE 社: NR-500)によってデジタル信号へと変換され，コンピュー 夕 (PC;DELL Inspiron 400:CPU Pentium3, 256Mbyte) で認識処理が行われる。

以上の実験を装置を用いて，母音の測定を行った。母音 の測定前に 10 分間の予備練習を行い， 1 母音につき 1 分間 

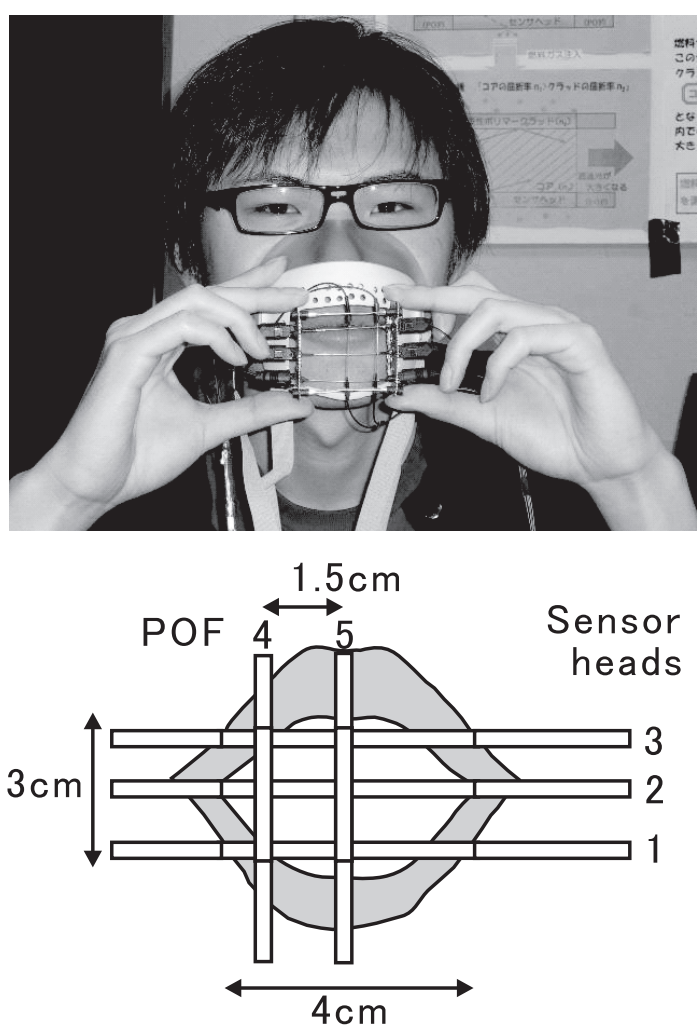

Fig. 4. Photograph and Schematic model of optical fiber microphone head.

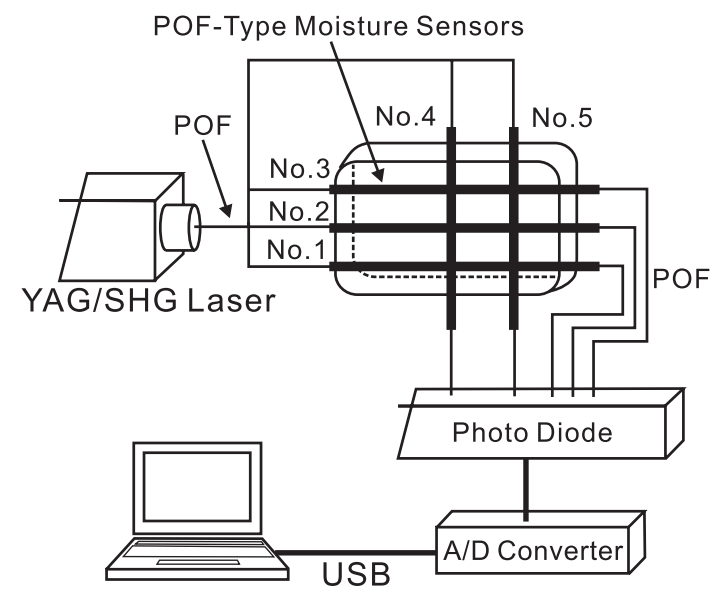

Fig. 5. Measurement system of moisture pattern in devoiced vowel breath.

測定を行った。母音に伴う呼気を吐いた後は，口の渴きや 呼吸の関係から十分な呼吸を行ってもらう。そのため, 測 定間隔には十分なゆとりをもつために 0.2 秒毎に 4.8 秒間 サンプリングしたものを 1 母音として測定した。

Fig. 6 には無声音母音に対応する各センサ出力の応答波 形の代表的な例を示す。Fig.6(a)の無声音母音「あ」の場 合，口を大きく開けて呼気を出すのですべてのセンサヘッ ドが大きく応答していることがわかる。また，(b)の「い」 の場合は下方に向けて呼気を出すので下側のセンサヘッド No.1, No.2 と縦中央 No.5 の反応が大きく, No.3, No.4 はほとんど応答しない。(c)の「う」の場合は口を窄めて呼 気を出すため, 中央の No.3 と No.5 のセンサヘッドのみが 応答する。(d) の「え」の場合は「い」と同様, 呼気を下方 に出すためにNo.2 と No.5 のセンサヘッドが応答するが, 呼気の方向が「い」より上に向くのでセンサヘッドNo.2 の 応答も大きくなる。さらに，(e)の「抽」の場合は「う」よ りも若干口を大きく開くので No.1 以外のセンサヘッドはす べて応答する，などの特徴が見てとれる。このように，各 母音に対応する無声音呼気に対して各々特徵ある水分分布 パターンを示すことが確認できた。

\section{4. 無声音母音の識別手法とその結果}

以上のような実験から, 各母音の無声音に対して特徵あ る信号出力を検出できることが明らかになったので，これ らの信号から各母音の識別を試みた。

無声音呼気では異なる母音同士であっても呼気の強さや センサの位置によってセンサ応答の大きさが異なるため, 単 純に波形のピーク部分の特徵のみでの認識は難しい。その ため, 認識には波形全体の情報を用いることが望ましいと 考えられる。また, 無声音呼気は音声等と同様に, その継 続時間は非線形に伸縮する。従って, 時間軸を非線形に伸 縮する時間正規化が必要となる。そこで本研究では, 文字 列の近似的照合や音声認識などでよく使われるアルゴリズ ムの一つである DP マッチング法を使用することとした。 DP マッチング法は動的計画法を用いたマッチング手法で あり，伸縮を伴うパターン間距離を最小とするような非線 形な対応関係を効率的に抽出できる ${ }^{(8)}$ 。したがって, 無声 音呼気の識別に対しても適していると考えられる。

最初に, Fig.6に示した各母音 1 パターンづつの代表的 なセンサー出力パターンをプロトタイプとして，DP マッ チングを行ってみた。入力值は， 5 本の POF センサからの 值を 0.2 秒毎に 4.8 秒間サンプルした 120 次元ベクトルの ものを用いた。しかし，その識別結果は認識率が $70 \%$ とそ う高い值ではなかった。この原因を調べるために，誤認識 したデータを比較したところ, 同じ母音でも唇の向きや息 の強弱によってセンサ出力パターンに違いがあるため生じ たことがわかった。従って, プロトタイプは前述の各母音 一つづつの 5 パターンでは不十分であり, 母音ごと複数パ ターンのプロトタイプが必要とされる。しかし，その必要 とされるパターンの数は明らかではない。そこで, 正しく, かつ，十分な数のプロトタイプを得るために非階層型クラ スタリングの手法 ${ }^{(9)}$ を用いることとした。

本研究では, 586 個の訓練データから Isodata アルゴリ ズムに DP マッチングの手法を併用することでプロトタイ プを作成した。Isodataアルゴリズムは，クラスタリング の方法の 1 つであり, 最も基本的な $\mathrm{K}$ 平均法に融合と分割 を取り入れることによって, クラス夕数が未知のものをク ラスタに分類していく方法である。ここでは, Isodataア ルゴリズムによって得られたクラスタ中心をプロトタイプ とすることにする。以下に，そのアルゴリズムを示す。 


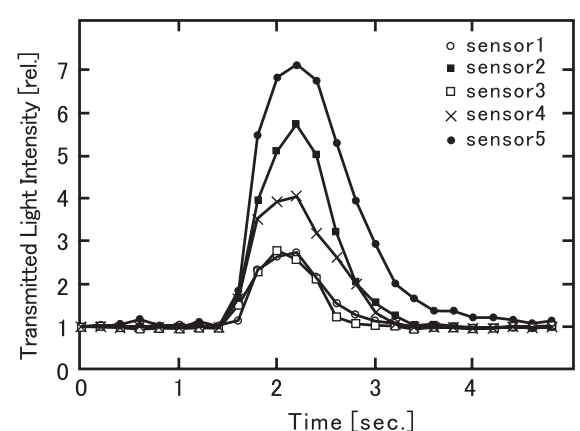

(a) " a"

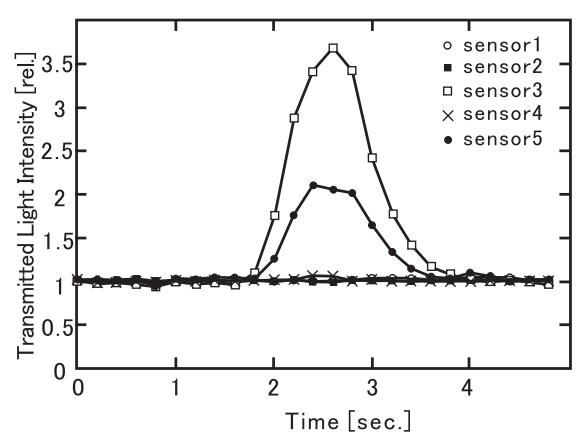

(c) " $u$ "

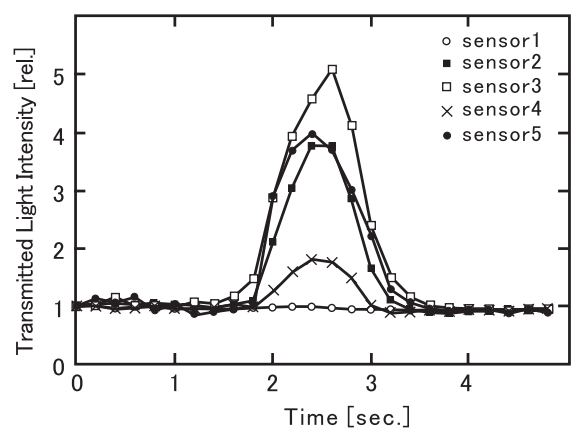

(e) "o"

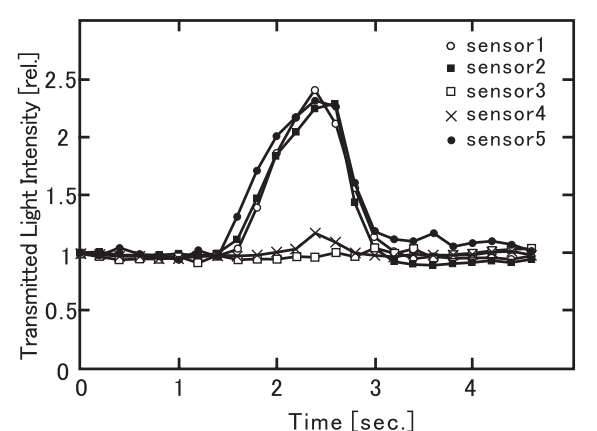

(b) " $i$ "

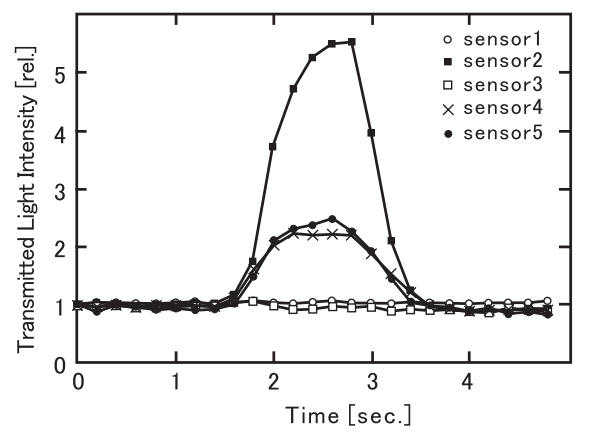

(d) "e"

Fig. 6. Observed moisture Patterns in five devoiced vowel breaths.

ステップ 1) パラメータの設定

以下を設定する。

クラスタ数 $N_{c}$ の初期值

クラスタ中心 $\boldsymbol{z}_{i}:\left(i=1, \cdots, N_{c}\right)$ の初期值

$\theta_{k}:$ クスタの最小要素数

$\theta_{s}:$ クラスタの分散に関する閾值

$\theta_{c}:$ クラスタ間の距離に関する閾值

ステップ 2) 訓練データのクラスタへの分類

すべての訓練デー夕 $\boldsymbol{x}$ を,

$$
\min _{i=1, \cdots, N_{c}}\left\|\boldsymbol{x}-\boldsymbol{z}_{i}\right\| \Rightarrow \boldsymbol{x} \in S_{i}
$$

によってクラスタ $S_{i}$ に分類する。ここで距離 $\left\|\boldsymbol{x}-\boldsymbol{z}_{i}\right\|$ は DP マッチングを用いて求める。

\section{ステップ 3) 要素数が最小要素数より少ないクラスタの除去}

クラスタを形成する要素の個数が $\theta_{k}$ よりも小さければ, そのクラスタと要素を除去する。
ステップ 4) クラスタ中心の更新

クラスタ中心の更新を，

$$
\boldsymbol{z}_{i}=\frac{1}{N_{i}} \sum_{\boldsymbol{x} \in S_{i}} \boldsymbol{x} \quad\left(i=1, \cdots, N_{c}\right)
$$

によって行う。ただし $N_{i}$ はクラスタ $S_{i}$ の要素数である。 ステップ 5) 終了

ステップ 2) からステップ 10)を 15 回繰り返せば終了 ステップ 6)

クラスタ数 $N_{c}$ が極端に多い場合，もしくは繰り返しの 回数が奇数回のとき，ステップ 7)へ。

クラスタ数 $N_{c}$ が極端に少ない場合, もしくは繰り返し の回数が偶数回のとき，ステップ9)へ。

ステップ 7) クラスタの融合

DP マッチングを用いて計算したクラスタ中心間距離 $D_{i j}=\left\|\boldsymbol{z}_{i}-\boldsymbol{z}_{j}\right\|$ が $\theta_{c}$ よりも小さいクラスタ $S_{i}$ と $S_{j}$ を次式により 1 つにまとめる。 
Table 1. Number of made clusters.

\begin{tabular}{l|l|l|l|l|l|}
\hline Subject & {$[\mathrm{a}]$} & {$[\mathrm{i}]$} & {$[\mathrm{u}]$} & {$[\mathrm{e}]$} & {$[\mathrm{o}]$} \\
\hline Subject 1 & 2 & 5 & 3 & 5 & 4 \\
Subject 2 & 1 & 1 & 2 & 6 & 5 \\
Subject 3 & 4 & 1 & 3 & 8 & 3 \\
Subject 4 & 4 & 3 & 2 & 5 & 4 \\
Subject 5 & 4 & 2 & 2 & 6 & 5 \\
\hline
\end{tabular}

Table 2. Result of vowel recognition for five devoiced breaths.

\begin{tabular}{l|c|l|l|l|l|l}
\hline Subject & The Average of [a]-[o] & {$[\mathrm{a}]$} & {$[\mathrm{i}]$} & {$[\mathrm{u}]$} & {$[\mathrm{e}]$} & {$[\mathrm{o}]$} \\
\hline Subject 1 & $95.8 \%$ & $87.0 \%$ & $97.0 \%$ & $100 \%$ & $98.9 \%$ & $97.9 \%$ \\
Subject 2 & $93.6 \%$ & $100 \%$ & $99.3 \%$ & $86.9 \%$ & $91.3 \%$ & $93.2 \%$ \\
Subject 3 & $94.6 \%$ & $87.1 \%$ & $88.5 \%$ & $100 \%$ & $98.9 \%$ & $97.9 \%$ \\
Subject 4 & $97.0 \%$ & $88.1 \%$ & $98.7 \%$ & $100 \%$ & $98.7 \%$ & $98.9 \%$ \\
Subject 5 & $97.4 \%$ & $88.7 \%$ & $100 \%$ & $99.2 \%$ & $100 \%$ & $95.0 \%$ \\
\hline
\end{tabular}

$$
\boldsymbol{z}_{i}=\frac{1}{N_{i}+N_{j}}\left(N_{i} \boldsymbol{z}_{i}+N_{j} \boldsymbol{z}_{j}\right)
$$

クラスタを 1 つにまとめたら， $N_{c}$ を 1 つ減らす。これ を， $\theta_{c}$ よりも小さいクラスタがなくなるまで繰り返す。

\section{ステップ 8)}

ステップ 2) に戻る。

\section{ステップ 9) クラスタの分割}

クラスタ $S_{i}$ の分散 $\boldsymbol{\sigma}_{i}$ の第 $k$ 次元の值

$$
\sigma_{i k}=\sqrt{\frac{1}{N_{i}} \sum_{x_{i k} \in S_{i}}\left(x_{i k}-z_{i k}\right)^{2}} \ldots \ldots \ldots \ldots \ldots
$$

の中で $\theta_{s}$ よりも大きいものがあればそのクラスタを分割 し， $N_{c}$ を 1 つ増やす。ここで， $x_{i k}$ と $z_{i k}$ は，それぞれク ラスタ $S_{i}$ の要素とクラスタ中心の第 $k$ 次元の值である。新 たなクラスタ中心には $\boldsymbol{z}_{j}$ と， $\boldsymbol{z}_{j}$ から最も離れた $\boldsymbol{x}_{j}$ を用 いる。これを $\theta_{s}$ よりも大きなクラスタがなくなるまで繰り 返す。

$$
\text { ステップ 10) }
$$

$$
\text { ステップ 2) に戻る。 }
$$

ここで，ステップ 1)での設定值や初期值は以下のように 設定した。

クラスタ数 $N_{c}$ は，母音数 5 より十分大きい数として 50 , クラスタ中心 $z_{i}$ は, 全訓練デー夕の平均 $\overline{\boldsymbol{x}}$ と標準偏差 $\boldsymbol{\sigma}$ を用いて均等になるように設定した。すなわち， $\boldsymbol{z}_{i}$ の第 $k$ 次元の值 $z_{i k}$ が, $\left[\bar{x}_{k}-\sigma_{k}, \bar{x}_{k}+\sigma_{k}\right]$ の範囲内で等間隔にな るように $N_{c}$ 個を配置した。また， $\theta_{k}$ は 3 に設定した。こ れらの設定值は，值を多少変えても結果には影響を与えな かった。

$\theta_{s}$ と $\theta_{c}$ はクラスタの融合や分割に関与し結果にも影響 を及ぼすため，以下のように設定した。

（1） ステップ 2) までを 1 回実行した後，クラスタ内標 準偏差の最も大きなものを $\theta_{s}$, クラスタ中心間距離の最も 大きなものを $\theta_{c}$ とする。

（2）Isodata アルゴリズムを実行する。その後，それぞ
れのクラスタに分類された訓練デー夕の母音分類の誤り率 を調べる。

(3) $\theta_{s}$ と $\theta_{c}$ を 1 づつ減じながら，Isodata アルゴリズ ムを実行し，それぞれ訓練データの母音分類の誤り率を調 べる。誤り率のもっとも小さい $\theta_{s}$ と $\theta_{c}$ を採用する。

また, 繰り返し回数は 15 回で十分収束し，15 回以上に しても結果には影響しなかった。

一方, 光ファイバ無声音マイクロホンを構成する 5 本の $\mathrm{POF}$ 水分センサの感度には若干のばらつきがあり, 各セン サ間の出力光強度変化を完全に均一にするのは難しい。ま た，複数の無声音母音に対して共通の POF センサヘッドの 出力変化が小さいときがある。これは，それぞれの母音の 特徵とみなすべきではあるが，極端に小さい場合には，こ れらの母音間での入力情報が減少してしまうことになる。 そこで, 訓練データをクラスタに分類するとき抄よび認識 を行うときに，センサ出力強度の最大值を各訓練データが 属するクラスタのクラスタ中心值の最大值と揃えるという 補正を行なった。

無声音認識の対象として，22〜24 歳の 5 人の男性に対 して行った無声音実験の測定デー夕を用いた。実験は 7 日 間行い，1 日目の測定データを無声音測定に慣れるための 予備練習とし，2〜4 日目のデータを標準パターン作成の訓 練デー夕とし，残りの 5 日〜 7 日目のデータを未知デー夕 として使用した。Isodata アルゴリズムによって得られた クラス夕数を Table 1 に示す。被験者 1 は計 19 , 被験者 2 は計 15 ，被験者 3 は計 19 , 被験者 4 は計 18 , 被験者 5 は 計 19 であった。この結果から, クラスタ中心を DP マッチ ングのプロトタイプとして使用して母音の認識実験を行っ た。この時, DP マッチングがプロトタイプと未知パター ンの識別を行うとき，2つのデー夕は同じ被験者から作成・ 採取したデー夕同士を比較する。その結果を Table 1 に示 す。Table 1 より明らかなように，本手法による結果では， 各被験者ともに $93 \%$ 以上と非常に高い認識率を示した。こ のことから，無声音による母音認識が有用であると考えら れる。 


\section{5. むすび}

発話が困難な人のコミュニケーション支援の方法として， 無声音呼気に含まれる水分に着目した言語認識システムを 提案した。新たに開発したPOF 水分センサを用いること で，各無声音母音に対応する呼気に対して特徴ある水分分 布パターンを示す応答が得られ, 光ファイバマイクロホン として利用可能であることを明らかにすることができた。 また，その出力信号に対して DP マッチング処理を行うこ とで無声音母音の識別が十分に可能であることが確認でき た。本論文では，研究の第一歩として単音の母音のみに対 しての検討しか行っていないが，今後，複数音の母音や複 数の被験者への対応，子音の認識への拡張などを試み，会 話に近いコミュニケーション支援装置として実際に役立つ ようにしていきたい。

(平成 20 年 1 月 21 日受付, 平成 20 年 3 月 19 日再受付)

\section{文献}

(1) M. Morisawa, Y. Amemiya, H. Kohzu, C.X. Liang, and S. Muto: "Plastic Optical Fibre Sensor for Detecting Vapor Phase Alcohol",Measurement Science and Technology, Vol.12, pp.877-881, (2001-6)

(2) S. Muto, O. Suzuki, T. Amano, and M. Morisawa: "A Plastic Optical Fibre Sensor for Real-time Humidity Monitoring", Measurement Science and Technology, Vol.14, pp746750, (2003-5)

（3）森澤正之・渡邊智也・武藤真三 :「プラスチック光ファイバーアミン センサの開発とそれを用いた魚肉の食品鮮度測定の試み」, 電学論 E, 125, pp.380-386, (2005-9)

(4) N. Alshabib, T. Soma, T. Akase, M. Morisawa, and S. Muto: "Fundamental Research of Plastic Optical Fiber Microphone Based on Detection of Devoiced Breath", Proc. of The 14th International Conference on Polymer Optical Fiber, pp.217220, (2005-9)

（5）真鍋宏幸・平岩 明・杉村利明:「無発声音声認識：筋電信号を用いた 声を伴わない日本語 5 母音の認識」, 信学論 D, J88-D2, pp.19091917, (2005-9)

（6）橋場参生・須貝保徳・泉隆・井野秀一・伊福部達：「喉頭摘出者 の発声を支援するウェアラブル人工喉頭の開発」, HI 学会研究報告 集, Vol.7, No.4, (2005-11)

（7） シャビーブ・ヌーリ・ 中西拓也・本間 聡・森澤正之・武藤真三： 「呼気中水分の光ファイバーセンシングによる無呼吸症候診断と声 帯機能失陥者用光ファイバー無音声マイクロホンの開発」, 第 25 回 日本生体医工学会 甲信越支部大会講演論文集（電子論文集）, 21 , (2005-9)

（8）長尾真執：「パターン情報処理」, pp.183-1985, コロナ社, 東京 (1983)

(9) G.H. Ball and D.J. Hall: "A clustering technique for summarizing multivariate data", Behv. Sci., 12, pp.153-155, (1967)
森 澤 正 之 (正員) 1962 年 11 月 24 日生。 1987 年 3 月山梨

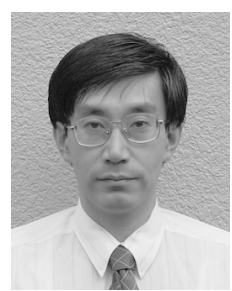
大学大学工学部電気工学科卒業。1989 年 3 月同大 学大学院工学研究科電気工学専攻修士課程修了。 同年 4 月山梨大学工学部助手。2003 年 8 月同助 教授。現在同准教授。主として有機薄膜，光ファ イバセンサに関する研究に従事。応用物理学会, 日本光学会, SPIE, IEEE 会員。博士 (工学)。

名 取 洋 - (非会員) 1983 年 10 月 5 日生。 2006 年 3 月山

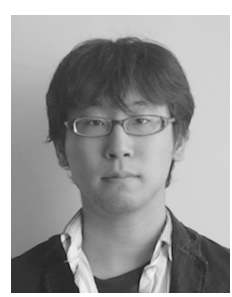
梨大学大学工学部コンピュータ・メディア工学科 卒業。同年 4 月山梨大学大学大学院医学総合教育 部コンピュータ・メディア専攻入学。現在に至る。 光ファイバセンサに関する研究に従事。応用物理 学会会員。

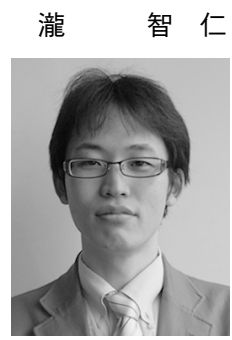

（非会員） 1983 年 3 月 6 日生。 2006 年 3 月山 梨大学大学工学部電気電子システム工学科卒業。 同年 4 月山梨大学大学大学院医学総合教育部電気 電子システム専攻入学。現在に至る。光ファイバ センサに関する研究に従事。応用物理学会会員。

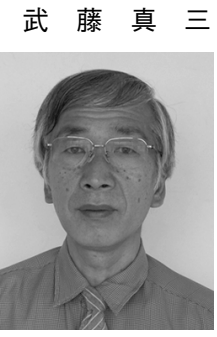

(非会員) 1947 年 4 月 5 日生。 70 年 3 月山梨大 学工学部電気工学科卒業。 72 年 3 月同大学大学 院工学研究科電気工学専攻修士課程修了。73 年 4 月山梨大学工学部助手。 89 年同助教授。現在, 同 教授。固体色素レーザ, 非線型光学, 高分子光デ バイス，光ファイバセンサなどの研究に従事。電 子情報通信学会, 応用物理学会, 日本光学会, 高 分子学会, SPIE, IEEE 会員。工学博士。 